\title{
Contractile Effects of Serotonin (5-HT) in the Rat Cauda Epididymis: Expression and Functional Characterization of 5-HT Receptors
}

\author{
Andre Mueller, Luiz R. A. Kiguti, ${ }^{1}$ (1) Erick J. R. Silva, and André S. Pupo \\ Department of Pharmacology, Institute of Biosciences, São Paulo State University, Botucatu-São Paulo, Brazil \\ Received October 4, 2018; accepted January 28, 2019
}

\begin{abstract}
Serotonin [5-hydroxytryptamine (5-HT)] exerts multiple central and peripheral functions. High concentrations of $5-\mathrm{HT}$ have been found in the epididymis, a ductal organ that plays pivotal roles in sperm transport and maturation. The contraction of the epididymal smooth muscle is essential for sperm transport and emission during ejaculation. The contributions of the epididymal 5-HT system to these events are poorly understood. Here, we assessed the contractile function of $5-\mathrm{HT}$ in the rat cauda epididymis (CE), pharmacologically targeting the receptor(s) and the reuptake mechanism involved in this system. Segments of CE duct from adult Wistar rats were set up in an organ bath system for isometric tension recordings, and concentration-response curves to $5-\mathrm{HT}$ and norepinephrine were obtained. 5-HT elicited concentration-dependent contractions of the CE duct $\left(\mathrm{pEC}_{50}=6.5 \pm 0.1\right)$ that were potentiated
\end{abstract}

with high potency by the norepinephrine transporter (NET) inhibitor desipramine and with low potency by the highly selective serotonin transporter inhibitor paroxetine, indicating that the NET is the major mediator of 5-HT reuptake in vitro. CE contractions to 5 -HT were antagonized by the $\alpha_{1}$-adrenoceptor $\left(\alpha_{1}-\mathrm{AR}\right)$ antagonist prazosin $\left(\mathrm{p} A_{2} \cong 8.9\right), 5-\mathrm{HT}_{2 \mathrm{~A} / 2 \mathrm{C}}$ antagonists ketanserin $\left(\mathrm{p} A_{2} \cong 9.4\right)$ and fluoxetine $\left(\mathrm{p} A_{2} \cong 7.4\right)$, and $5-\mathrm{HT}_{1 \mathrm{~A}}$ ligands WAY $100635\left(\mathrm{p} A_{2} \cong 8.9\right)$ and buspirone $\left(\mathrm{p} A_{2} \cong 7.3\right)$. Reverse transcriptase polymerase chain reaction analysis demonstrated that $5-\mathrm{HT}_{1 \mathrm{~A}}$ and $5-\mathrm{HT}_{2 \mathrm{~A}}$ transcripts are highly abundant in the cauda epididymis, whereas $5-\mathrm{HT}_{2 \mathrm{C}}$ transcript was not found. Altogether, our results reveal that contractions of the $\mathrm{CE}$ duct to 5 -HT encompasses at least activation of $\alpha_{1}$-ARs and $5-\mathrm{HT}_{1 \mathrm{~A}}$ and $5-\mathrm{HT}_{2 \mathrm{~A}}$ receptors, providing new insights into the roles of $5-\mathrm{HT}$ on the epididymal function.

\section{Introduction}

Serotonin [5-hydroxytryptamine (5-HT)] is a largely distributed biogenic monoamine exerting several effects in both neuronal and non-neuronal tissues. In the central nervous system 5-HT controls behavioral processes and other functions such as emesis, body temperature, ejaculation, and circadian rhythms (Berger et al., 2009). Outside the central nervous system 5 -HT is involved in a number of functions, such as vasoconstriction, nociception, intestinal motility and secretion, platelet aggregation, uterine smooth muscle contraction, among others (Hoyer et al., 1994; Berger et al., 2009). This myriad of actions of 5 -HT are mediated by interactions with 14 different 5-HT receptors, which are classified into seven families $\left(5-\mathrm{HT}_{1-7}\right)$. All 5-HT receptors are metabotropic seven transmembrane domain receptors (or G protein-coupled

This work was supported by São Paulo Research Foundation [Grants 2017/ 15175-1 and 2015/08227-0]. This study was supported in part by the Federal University of Mato Grosso and Coordenação de Aperfeiçoamento de Pessoal de Nível Superior-Brazil [Finance Code 001].

${ }^{1}$ Current affiliation: Department of Pharmacology, Universidade Estadual de Campinas, Campinas-SP, Brazil.

A.M. and L.R.A.K. contributed equally to this work as first authors.

E.J.R.S. and A.S.P. contributed equally to this work.

https://doi.org/10.1124/jpet.118.254110. receptors) (Alexander et al., 2017a), with the exception of $5-\mathrm{HT}_{3}$, which is an ionotropic (cation-permeable) receptor (Alexander et al., 2017b). The variety of 5-HT receptor subtypes reflects the extraordinary biologic relevance of 5-HT as a neurotransmitter, as well as a paracrine and autocrine signaling molecule.

Concerning the metabotropic 5 -HT receptors, the $5-\mathrm{HT}_{1}$ and $5-\mathrm{HT}_{2}$ classes are comprised of five $\left(5-\mathrm{HT}_{1 \mathrm{~A}}, 1 \mathrm{~B}, 1 \mathrm{D}, 1 \mathrm{E}, 1 \mathrm{~F}\right)$

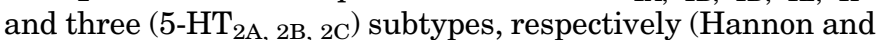
Hoyer, 2008; Alexander et al., 2017a). In agreement with the widespread distribution of $5-\mathrm{HT}$ receptors, the $5-\mathrm{HT}_{1 \mathrm{~A}}$, $5-\mathrm{HT}_{1 \mathrm{~B}}$, and $5-\mathrm{HT}_{2 \mathrm{~A}}$ subtypes have been described in male reproductive tissues. 5-HT is known to regulate testicular blood flow and testosterone secretion (Kinson et al., 1973), and to contract the smooth muscle of male reproductive organs, such as the seminal vesicle (Kim and Paick, 2004), vas deferens (Hay and Wadsworth, 1982; Campos et al., 1999; Pedroso et al., 2017), and prostate (Steidle et al., 1989), through activation of the $5-\mathrm{HT}_{1}$ and/or $5-\mathrm{HT}_{2}$ receptor subtypes. Interestingly, high concentrations of 5-HT have been found in the epididymis, a ductal organ that plays a crucial role in sperm transport, concentration, maturation, and storage until ejaculation (Kormano and Penttilä, 1968; Anderson et al., 1979). Jiménez-Trejo et al. (2007) revealed that the rat caput

ABBREVIATIONS: AR, adrenoceptor; $\mathrm{CE}$, cauda epididymis; $\mathrm{CR}$, concentration ratio; $\mathrm{CRC}$, concentration-response curve; $E_{\text {max }}$, maximal response; 5-HT, serotonin (5-hydroxytryptamine); NET, norepinephrine transporter; PCR, polymerase chain reaction; RT-PCR, reverse transcriptase polymerase chain reaction; SERT, serotonin transporter; SSRI, selective serotonin reuptake inhibitor. 
epididymis possesses a local serotonergic system that includes the expression of 5-HT biosynthetic enzymes, 5-HT receptors (5- $\mathrm{HT}_{1 \mathrm{~A}}, 5-\mathrm{HT}_{2 \mathrm{~A}}$, etc.), and serotonin transporters by epididymal epithelial and non-epithelial cells. Notwithstanding, the contribution of 5-HT to epididymal physiology is still poorly understood.

It has been reported that 5 -HT stimulates anion secretion via $5-\mathrm{HT}_{1 \mathrm{~B}}$ and $5-\mathrm{HT}_{2 \mathrm{~B}}$ receptors in rat cauda epididymal cell primary cultures (Leung et al., 1999), suggesting that 5-HT plays a role in the regulation of epididymal luminal content and sperm quiescence during storage in the epididymis. Furthermore, administration of exogenous 5 -HT in rats resulted in fluid accumulation in the epididymis (Singh et al., 1987). In men, high blood 5-HT levels were associated with poor sperm count and motility (Gonzales et al., 1992), and treatment with the antidepressant paroxetine, a selective serotonin reuptake inhibitor (SSRI), caused ejaculatory difficulties and increased sperm DNA fragmentation (Tanrikut et al., 2010). Despite these negative outcomes, SSRIs, such as dapoxetine, can be used in the pharmacotherapy of premature ejaculation (Giuliano and Clément, 2005; Rowland et al., 2010; Abu El-Hamd and Abdelhamed, 2018). It is thought that the effects of SSRIs on the regulation of ejaculatory function are mediated by increasing 5-HT signaling in the central nervous system. Nevertheless, peripheral mechanisms in the male reproductive organs could also be involved in these clinical outcomes (Jannini et al., 2015).

Epididymal epithelial cells are surrounded by a smooth muscle layer, in which the thickness increases from the proximal (caput) to distal (cauda) epididymis. In the cauda epididymis (CE), the thicker smooth muscle layer is densely innervated by postganglionic sympathetic nerve fibers that release norepinephrine (Ricker, 1998; Silva et al., 2010). These sympathetic nerve fibers play a crucial role in the contraction of the CE smooth muscle, which is paramount for sperm transport during the emission phase of ejaculation and hence for reproduction (Ricker et al., 1997; Pacini et al., 2018). Likewise, the presence of a dense network of serotonergic nerve fibers has been detected in the CE (Leung et al., 1999), although the role of 5-HT in the contraction of the epididymal smooth muscle remains elusive.

Taking this into account and considering: 1) the ability of 5 -HT to contract smooth muscle in reproductive organs, 2) the existence of a local serotoninergic system in the epididymis, and 3) the reproductive outcomes of SSRI drugs, we hypothesized that 5-HT contracts CE smooth muscle. Thus, we systematically assessed the contractions induced by 5 - $\mathrm{HT}$ in the rat $\mathrm{CE}$ smooth muscle in vitro, and investigated the roles of 5 -HT receptor subtypes and reuptake systems in the pharmacological events mediated by 5 -HT in this tissue.

\section{Materials and Methods}

Animals and Drugs. Adult male Wistar rats (90-150 days old) were maintained under controlled conditions (12-hour/12-hour light/ dark cycle, $25 \pm 2{ }^{\circ} \mathrm{C}$, and $40 \%-70 \%$ humidity) with food and water ad libitum. All animal procedures were approved by the Ethics Committee for the Use of Experimental Animals from the Institute of Biosciences of Botucatu, São Paulo State University (Process No. 749/15) and were in agreement with the Guide for the Care and Use of Laboratory Animals (National Institutes of Health) and Animal in Research: Reporting In Vivo Experiments guidelines (Kilkenny et al.,
2010). The drugs used in the experiments were obtained from the following sources: L-(-)-norepinephrine bitartrate salt monohydrate, serotonin $\mathrm{HCl}$, ketanserin tartrate, WAY 100635, buspirone, and corticosterone were purchased from Sigma; fluoxetine $\mathrm{HCl}$ was purchased from Fagron; paroxetine was purchased from Tocris; and desipramine $\mathrm{HCl}$, prazosin $\mathrm{HCl}$, yohimbine $\mathrm{HCl}$, and ( \pm )-propranolol $\mathrm{HCl}$ were purchased from Research Biochemicals Inc.

In Vitro Contraction Studies. Contraction experiments were conducted following the procedure detailed in Pacini et al. (2018). Rats were killed by decapitation and the epididymis was carefully excised. The CE was uncoiled, cleaned of adherent tissues, and freed from intraluminal content by flushing $1 \mathrm{ml}$ of nutrient solution through a blunt-ended 30 gauge needle. For digital recording of isometric contractions, segments of the distal CE ( 1.0 cm in length), corresponding to region 19 according to Jelinsky et al. (2007), were mounted in organ baths under $1.0 \mathrm{~g}$ of resting tension in a modified Tyrode's solution (138 mM NaCl, $5.7 \mathrm{mM} \mathrm{KCl}, 1.8 \mathrm{mM} \mathrm{CaCl}_{2}, 0.36 \mathrm{mM}$ $\mathrm{NaH}_{2} \mathrm{PO}_{4}, 15 \mathrm{mM} \mathrm{NaHCO}$, and $5.5 \mathrm{mM}$ dextrose) prepared in glass-distilled deionized water, maintained at $30^{\circ} \mathrm{C}$ and $\mathrm{pH} 7.4$, and continuously bubbled with $95 \% \quad \mathrm{O}_{2} / 5 \% \quad \mathrm{CO}_{2}$. After a 30-minute stabilization period, CE segments were challenged with $80 \mathrm{mM} \mathrm{KCl}$ until reproducible contractions were obtained. Then, cumulative concentration-response curves (CRCs) to norepinephrine or 5-HT were obtained and taken as control curves. All curves were conducted in the presence of a cocktail of inhibitors containing corticosterone $(10 \mu \mathrm{M})$, yohimbine $(0.1 \mu \mathrm{M})$, and propranolol $(0.1 \mu \mathrm{M})$ to block the monoamine uptake not mediated by the norepinephrine transporter (NET), serotonin transporter (SERT), and $\alpha_{2^{-}}$and $\beta$-adrenoceptors (ARs), respectively.

To investigate the role of the NET and/or SERT, CRCs to 5-HT and norepinephrine were built up in the presence of fluoxetine, paroxetine (selective SERT inhibitors), and desipramine (selective NET inhibitor). The involvement of $\alpha_{1}$-ARs was investigated using prazosin $\left(\alpha_{1}\right.$-AR antagonist) and that of 5-HT receptors was investigated using ketanserin (5- $\mathrm{HT}_{2 \mathrm{~A} / 2 \mathrm{C}}$ antagonist), WAY 100635 (5- $\mathrm{HT}_{1 \mathrm{~A}}$ antagonist), buspirone (5- $\mathrm{HT}_{1 \mathrm{~A}}$ partial agonist), or fluoxetine (SERT inhibitor with high affinity for $5-\mathrm{HT}_{2 \mathrm{~A} / 2 \mathrm{C}}$ ). All inhibitors/antagonists were previously incubated for 45 minutes to allow equilibration, and then a new CRC to either norepinephrine or 5-HT was obtained. Contractions were expressed as percentage of maximal contraction of the control curves. The potencies of norepinephrine and 5-HT in the absence and presence of antagonists are presented as $\mathrm{pEC}_{50}$ values, i.e., the negative logarithm of the concentration of 5-HT or norepinephrine producing $50 \%$ of its maximal response $\left(E_{\max }\right)$. The effects of each concentration of norepinephrine or 5-HT were measured as the peak of the respective induced contraction of agonist.

Schild Analysis. Antagonist potencies and affinities were evaluated by Schild analysis (Arunlakshana and Schild, 1959). The parallel rightward displacements induced by each antagonist concentration on $5 \mathrm{HT}$ or norepinephrine CRCs were quantified and used to calculate the concentration ratio (CR), which is the ratio between equieffective norepinephrine or 5-HT concentrations in the presence and absence of antagonist. The $\mathrm{CR}$ was plotted as $\log (\mathrm{CR}-1)$ versus the respective antagonist concentration in a Schild plot and analyzed by linear regression. The slopes of linear regressions were calculated, and when not different from unity the intercept in abscissa $\left(\mathrm{p} A_{2}\right)$ was taken as the antagonist dissociation constant $\left(\mathrm{p} K_{\mathrm{B}}\right)$. However, as in most assays, since the slopes in the Schild plots were much lower than 1.0 , the $\mathrm{p} A_{2}$ values were taken as estimates of antagonist potencies calculated from the formula $\mathrm{p} A_{2}=\log (\mathrm{CR}-1)-\log [\mathrm{B}]$, where $[\mathrm{B}]$ is the lowest effective antagonist concentration.

Reverse Transcriptase Polymerase Chain Reaction. Reverse transcriptase polymerase chain reaction (RT-PCR) was performed to detect each specific gene target. Total RNA from epididymal regions (initial segment, caput, corpus, and cauda), testis, and brain was extracted using TRIzol Reagent (Thermofisher) according to the manufacturer's instruction, followed by DNase treatment (DNase I Amplification Grade; Invitrogen) and first strand cDNA synthesis 
(Thermoscript RT-PCR kit; Invitrogen). Oligo(dT)-primed cDNA was synthesized from total RNA $(2 \mu \mathrm{g})$ for 1 hour at $55^{\circ} \mathrm{C}$ in a reaction volume of $20 \mu \mathrm{l}$. The resulting cDNA $(2 \mu \mathrm{l})$ was amplified by polymerase chain reaction (PCR) (SimpliAmp; Applied Biosystems) in a final volume of $20 \mu$ l containing $20 \mathrm{mM}$ Tris- $\mathrm{HCl}(\mathrm{pH} 8.4), 50 \mathrm{mM}$ $\mathrm{KCl}, 1.5 \mathrm{mM} \mathrm{MgCl} 2,0.2 \mathrm{mM}$ deoxynucleotide triphosphate, $1 \mathrm{U}$ Thermus aquaticus DNA polymerase, and $0.4 \mu \mathrm{M}$ of each sense and antisense primer used to amplify specific nucleotide sequences present in Htr1a, Htr1b, Htr2a, Htr2b, Htr2c, and Ppia transcripts. Primer sequences, GenBank accession numbers, corresponding base sites, sizes of the PCR products, and PCR conditions are given in Table 1. Primers for Htr1a, Htr1b, Htr2b, Htr2c, and Ppia were designed using Primer-BLAST (https://www.ncbi.nlm.nih.gov/tools/ primer-blast/) and spanned at least one intron to ensure that PCR products were from cDNA and not genomic DNA. Primers for Htr2a were designed as described by Reist et al. (2003). Routinely, no-template negative control PCR reactions were performed to assess genomic DNA contamination in the template RNA. Positive control was employed to check that the PCR conditions used could successfully amplify the target sequences. DNA samples (10 $\mu \mathrm{l})$ were loaded onto agarose gels $(1.5 \%$, w/v) containing $10 \mu \mathrm{g} / \mathrm{ml}$ Sybr Safe DNA Gel Stain (Invitrogen) and the results were imaged using the G:BOX XR5 (Syngene) imaging system.

Statistical Analysis. Curve fitting was performed by nonlinear regression using the three-parameter logistic equation from GraphPad Prism version 6 (GraphPad Software, San Diego, CA), and the $E_{\max }, \mathrm{pEC}_{50}$, and $\mathrm{p} A_{2}$ values were calculated accordingly. All values are shown as mean \pm S.E.M. of $n$ independent experiments. Differences between mean values were tested for statistical significance $(P<0.05)$ using ANOVA, followed by Dunnet's test for multiple comparisons.

\section{Results}

5-HT Contracts the Rat Cauda Epididymis Smooth Muscle. 5-HT elicited concentration-dependent contractions, presenting a $\mathrm{pEC}_{50}$ value of $6.45 \pm 0.14$ and a maximal response that corresponded to $\sim 45 \%$ of the norepinephrine $E_{\max }$ value (Fig. 1A). As shown in the typical recordings presented in Fig. 1, C and D, the contractions induced by 5-HT were less sustained than those produced by norepinephrine.

Uptake of 5-HT in the Rat Cauda Epididymis Is Mainly Driven by the NET Rather Than the SERT. To investigate the participation of the 5-HT reuptake system, CRCs to 5-HT were performed in the absence and presence of different concentrations of SERT inhibitors (Fig. 2) and the influence of the reuptake was estimated in terms of agonist CRs measured at the $\mathrm{EC}_{50}$ values (Table 2).

At low concentrations (1-10 nM), both selective SERT inhibitors paroxetine and fluoxetine were ineffective in potentiating 5-HT-induced contractions in the $\mathrm{CE}$ duct (Fig. 2, A and E; Table 2). These low concentrations of both paroxetine and fluoxetine did not affect CRCs to norepinephrine (Fig. 2, B and F). However, at higher concentrations, 100-1000 nM of paroxetine increased the potency of 5-HT and norepinephrine by up to $\sim 5$ - and $\sim 30$-fold, repectively (Fig. 2, C and D; Table 2). Conversely, 30-100 nM of fluoxetine reduced the potencies of 5 -HT by up to $\sim 3$-fold in the CE duct (Fig. 2G; Table 2); at such high concentrations, fluoxetine did not affect the potencies of norepinephrine in the CE duct (Fig. 2H; Table 2).

These data indicated that 5 -HT is not taken up by the SERT in the CE duct, and that the NET could play such a role, as suggested by the effects of high concentrations of paroxetine on both 5-HT- and norepinephrine-induced contractions of the $\mathrm{CE}$ duct. We evaluated whether the NET could participate in the removal of 5-HT in the CE duct using the selective NET inhibitor desipramine. At concentrations of 10 and $30 \mathrm{nM}$, desipramine potentiated the effects of 5-HT in the CE duct by up to 4 -fold (Fig. 2I; Table 2), whereas $10 \mathrm{nM}$ of desipramine potentiated the effects of norepinephrine by $\sim 10$-fold (Fig. $2 \mathrm{~J}$; Table 2).

$\alpha_{1}$-Adrenoceptors and 5-HT $\mathrm{T}_{1 \mathrm{~A}}$ and 5-HT $\mathrm{H}_{2 \mathrm{~A} / 2 \mathrm{C}}$ Receptors Are Involved in the 5-HT-Induced Contractions of the Rat Cauda Epididymis. To investigate the receptors involved in the contractions induced by 5 -HT, CRCs were built in the absence and presence of selective antagonists. Since 5-HT has been shown to activate adrenoceptors (Innes, 1962; Purdy et al., 1987; Shaw et al., 2000), and considering that these receptors are abundantly expressed in the CE (Ventura and Pennefather, 1991; Queiróz et al., 2002; White et al., 2013; Pacini et al., 2018), we determined the effects of the selective $\alpha_{1}$-AR antagonist prazosin on 5-HT-induced contractions in the CE duct. In fact, low concentrations (3-100 nM) of prazosin antagonized the contractions induced by 5 -HT with a potency measured as a $\mathrm{p} A_{2}$ value of 8.89 , which well correlated to the potency obtained against norepinephrine $\left(\mathrm{p} A_{2}=8.92\right)($ Fig. 3 ; Table 3), indicating that $\alpha_{1}$-ARs are involved in the contractions induced by 5 -HT. However, the slope in the Schild plot

TABLE 1

Primers and conditions for RT-PCR

\begin{tabular}{|c|c|c|c|c|c|c|c|c|}
\hline \multirow{2}{*}{ Gene } & \multirow{2}{*}{ Primer Sequence } & \multirow{2}{*}{$\begin{array}{l}\text { Amplicon } \\
\text { Size }\end{array}$} & \multirow{2}{*}{$\begin{array}{l}\text { Accession } \\
\text { Number }\end{array}$} & \multirow{2}{*}{$\begin{array}{c}\text { Initial } \\
\text { Denaturation }\end{array}$} & \multicolumn{3}{|c|}{35 Cycles } & \multirow{2}{*}{$\begin{array}{c}\text { Final } \\
\text { Elongation }\end{array}$} \\
\hline & & & & & Denaturation & Annealing & Elongation & \\
\hline & & $b p$ & & ${ }^{\circ} \mathrm{C} / \mathrm{min}$ & ${ }^{\circ} \mathrm{C} / \mathrm{s}$ & ${ }^{\circ} \mathrm{C} / \mathrm{s}$ & ${ }^{\circ} \mathrm{C} / \mathrm{s}$ & ${ }^{\circ} \mathrm{C} / \mathrm{min}$ \\
\hline \multirow[t]{2}{*}{ Htr1a } & Forward: 5'-GTCACCTGCGACCTGTTTAT-3' & 286 & NM_012585.1 & $95 / 2$ & $95 / 60$ & $58 / 60$ & $72 / 90$ & $72 / 3$ \\
\hline & Reverse: 5'-CGAAAGTGGAGTAGATGGTGT-3' & 286 & NM_012585.1 & $95 / 2$ & $95 / 60$ & $58 / 60$ & $72 / 90$ & $72 / 3$ \\
\hline \multirow[t]{2}{*}{$H t r 1 b$} & Forward: 5'-CACTGATGCGGTGGACTATT-3' & 217 & NM_022225.1 & $95 / 2$ & $95 / 60$ & $58 / 60$ & $72 / 75$ & $72 / 3$ \\
\hline & Reverse: 5'-GAGCAGGGTGGGTAAATAGAA-3' & 217 & NM_022225.1 & $95 / 2$ & $95 / 60$ & $58 / 60$ & $72 / 75$ & $72 / 3$ \\
\hline \multirow[t]{2}{*}{$H t r 2 a$} & Forward: 5'-AGCTGCAGAATGCCACCAACTAT-3' & 322 & NM_017254.1 & $95 / 2$ & $95 / 60$ & $60 / 60$ & $72 / 75$ & $72 / 3$ \\
\hline & Reverse: 5'-GGTATTGGCATGGATATACCTAC-3' & 322 & NM_017254.1 & $95 / 2$ & $95 / 60$ & $60 / 60$ & $72 / 75$ & $72 / 3$ \\
\hline \multirow[t]{2}{*}{$H t r 2 b$} & Forward: 5'-CTGTGTCCTGCCTGGTTATT-3' & 224 & NM_017250.1 & $95 / 2$ & $95 / 60$ & $58 / 60$ & $72 / 75$ & $72 / 3$ \\
\hline & Reverse: 5'-TTGACCACATCAGCCTCTATTC-3' & 224 & NM_017250.1 & $95 / 2$ & $95 / 60$ & $58 / 60$ & $72 / 75$ & $72 / 3$ \\
\hline \multirow[t]{2}{*}{$H t r 2 c$} & Forward: 5'-GCTAGCGGGTTGTCAACTAT-3' & 322 & NM_012765.3 & $95 / 2$ & $95 / 60$ & $60 / 60$ & $72 / 75$ & $72 / 3$ \\
\hline & Reverse: 5'-CGACGATTGAAAGTGCTGGC-3' & 322 & NM_012765.3 & $95 / 2$ & $95 / 60$ & $60 / 60$ & $72 / 75$ & $72 / 3$ \\
\hline \multirow[t]{2}{*}{ Ppia } & Forward: 5'-AGCACTGGGGAGAAAGGATT-3' & 174 & NM_017101.1 & $95 / 2$ & $95 / 60$ & $60 / 45$ & $72 / 60$ & $72 / 3$ \\
\hline & Reverse: 5'-GATGCCAGGACCTGTATGCT-3' & 174 & NM_017101.1 & $95 / 2$ & $95 / 60$ & $60 / 45$ & $72 / 60$ & $72 / 3$ \\
\hline
\end{tabular}

bp, base pair. 

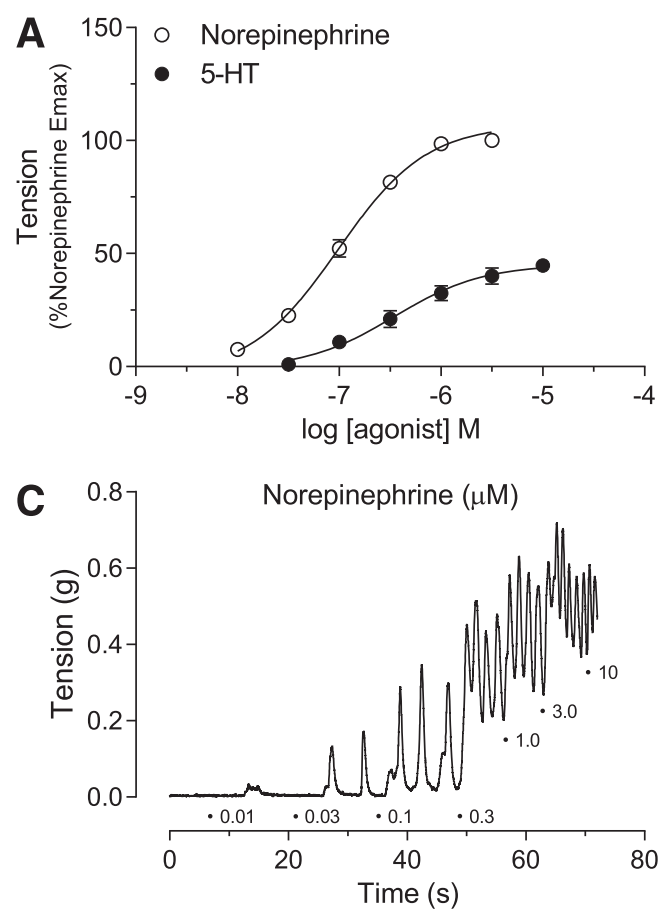

B

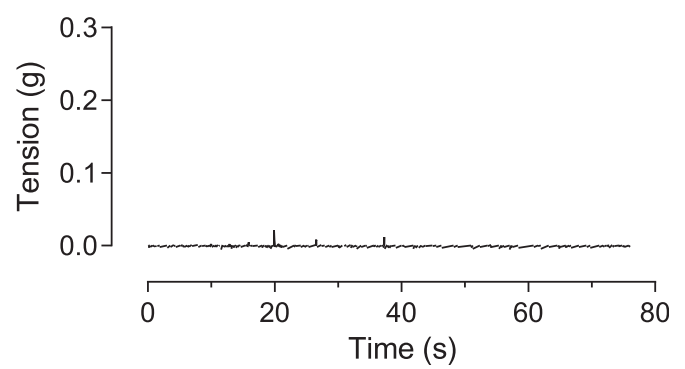

D

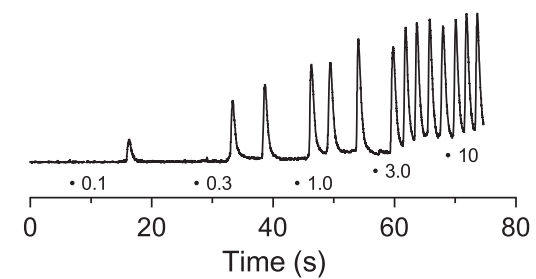

Fig. 1. Contractile effects of 5-HT and norepinephrine in the rat CE duct. (A) Mean concentration-response curves in the presence of cocktail of inhibitors for contractions induced by norepinephrine $(O)$ and 5-HT $(-)$, as measured by the peak of the phasic effect. Values represent mean \pm S.E.M. of 11 and seven independent experiments to norepinephrine and 5-HT, respectively. (B) Representative recording of baseline before CRCs. (C and D) Representative recordings of contractions of the CE duct in vitro to norepinephrine and 5-HT, respectively.

for prazosin against 5-HT was much lower than theoretical unity (Fig. 3, A and C; Table 3), while the antagonism presented against norepinephrine was consistent with a competitive antagonism (Fig. 3, B and C; Table 3). Therefore, the effects of subtype-selective 5-HT receptor antagonists were evaluated in the presence of $100 \mathrm{nM}$ prazosin to prevent activation of $\alpha_{1}$-ARs by 5 -HT.

Increasing concentrations of the $5-\mathrm{HT}_{2 \mathrm{~A}} / 5-\mathrm{HT}_{2 \mathrm{C}}$ receptor antagonist ketanserin (1-30 $\mathrm{nM}$ ) produced rightward shifts on the CRCs to 5-HT, although insurmountable antagonism was observed with concentrations from 3 to $30 \mathrm{nM}$, which reduced the $E_{\max }$ value for 5-HT (Fig. 4A). To further investigate the putative serotonergic receptors involved in 5-HT-induced contraction in the $\mathrm{CE}$ duct, the contraction evoked by 5 -HT was evaluated in the presence of increasing concentrations of WAY 100635 (5- $\mathrm{HT}_{1 \mathrm{~A}}$ antagonist) and buspirone (5- $\mathrm{HT}_{1 \mathrm{~A}}$ partial agonist). Both acted as noncompetitive antagonists (slope less than unity), providing estimated $\mathrm{p} A_{2}$ values of $8.90 \pm 0.04$ and $7.34 \pm 0.14$, respectively (Fig. 4, B and C; Table 3). At concentrations in which fluoxetine displays affinity at $5-\mathrm{HT}_{2 \mathrm{~A}}$ and $5-\mathrm{HT}_{2 \mathrm{C}}$ receptors (Bonhaus et al., 1997; $\mathrm{Ni}$ and Miledi, 1997; Owens et al., 1997; Rothman et al., 2000), 5-HTinduced contractions of the $\mathrm{CE}$ duct were right shifted in a surmountable manner with an estimated $\mathrm{p} A_{2}$ value of $7.44 \pm$ 0.16 (Fig. 4D; Table 3).

Htr1a, Htr1b, Htr2a, and Htr2b, but Not the Htr2c Transcript, Are Expressed in the Rat Epididymis. Based on the pharmacological data, we performed conventional RT-PCR assays to investigate the expression of Htrla, $H t r 1 b, H t r 2 a, H t r 2 b$, and Htr2c transcripts along the rat epididymis (initial segment, caput, corpus, and cauda regions). The detection of these transcripts either in the brain or testis was used as positive controls (Fig. 5). Both the Htr1a and Htr2b transcripts were detected in the corpus and CE, while the Htr2a transcript appeared in the CE only (Fig. 5). Conversely, the Htr $1 b$ transcript was found to be ubiquitously expressed throughout the epididymis, with higher abundance in the CE (Fig. 5). The expression of the Htr2c transcript was not detected in any region of the epididymis (Fig. 5).

\section{Discussion}

We revealed that 5 -HT is a contractile agent in the rat $\mathrm{CE}$. The $5-\mathrm{HT}_{1 \mathrm{~A}}$ and $5-\mathrm{HT}_{2 \mathrm{~A}}$ receptors are involved in the 5-HTmediated contractions of the rat CE smooth muscle, suggesting that this serotonergic transmission might contribute to the coordinated contraction of the $\mathrm{CE}$ duct during the transport of spermatozoa within the epididymis. This epididymal event is crucial for the production of a fertile ejaculate since its disruption may affect fertility (Ricker et al., 1997; Solomon et al., 1997; Kempinas et al., 1998). Indeed, the blockade of epididymal and vas deferens contractions during the emission phase of ejaculation has been proposed as a pharmacological strategy for male contraception (Sanbe et al., 2007; White et al., 2013). Our results underscore that the serotonergic system in the epididymis should also be considered when targeting epididymal/vas deferens smooth muscle as a potential target for male contraception.

When used at concentrations within their selectivity windows, some of the most selective SERT inhibitors including paroxetine $(0.1-10 \mathrm{nM})$ and fluoxetine $(1-10 \mathrm{nM})$ were unable to increase the potency of 5-HT in the $\mathrm{CE}$, indicating that the SERT is not involved in the removal of 5-HT. However, paroxetine at concentrations higher than $100 \mathrm{nM}$ caused a 5 -fold increase in the potency of 5-HT, which likely results from paroxetine's selectivity loss, and hence NET inhibition 
A

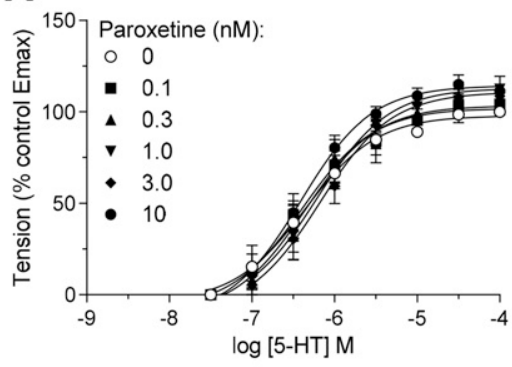

C

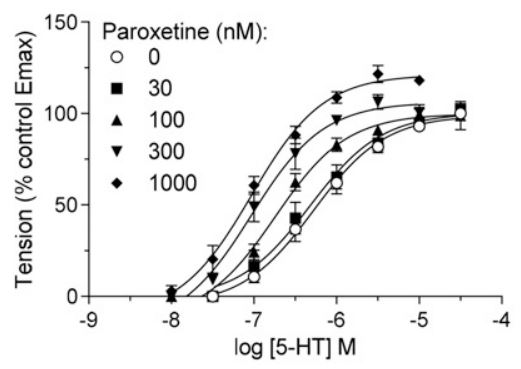

E

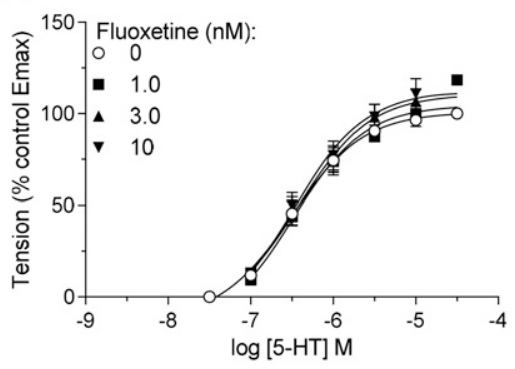

G

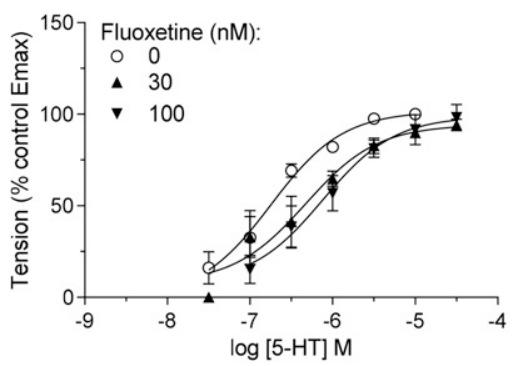

1

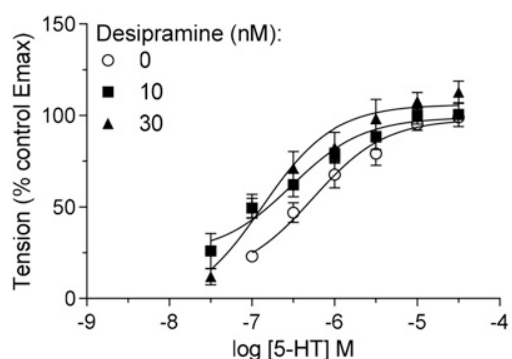

B

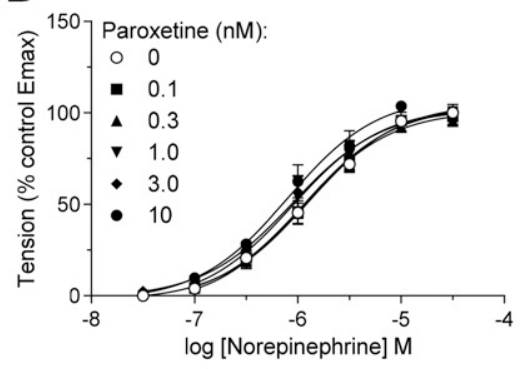

D

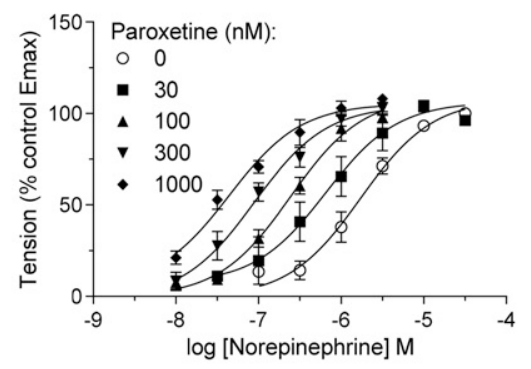

$\mathbf{F}$

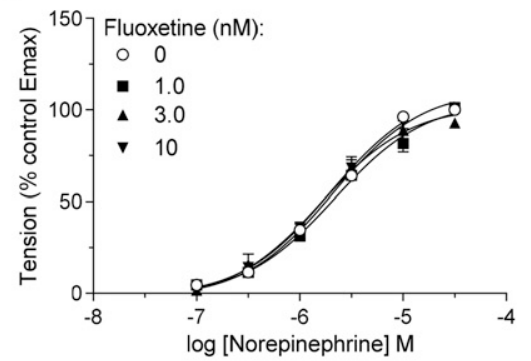

Fig. 2. Differential effects of SERT and NET inhibitors on the 5-HT- and norepinephrine-induced contraction in the rat $\mathrm{CE}$ duct. Concentrationresponse curves to 5-HT are shown on the left and norepinephrine are shown on the right, in the presence of different concentrations of the selective SERT inhibitors paroxetine (A-D) and fluoxetine $(\mathrm{E}-\mathrm{H})$ and in the presence of the NET inhibitor desipramine (I and J). Each symbol represents the mean and the vertical bars, when larger than the symbols, represent the S.E.M. of independent experiments performed with $\mathrm{CE}$ ducts from four rats.
H



J

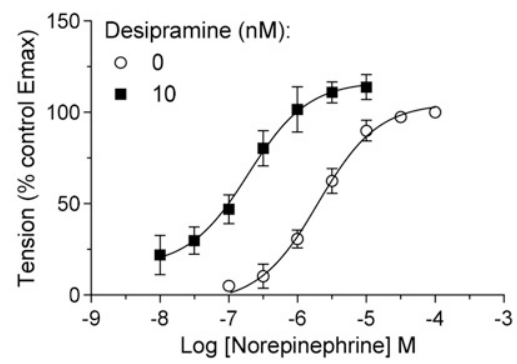

(Bolden-Watson and Richelson, 1993; Owens et al., 1997; Tatsumi et al., 1997). In fact, at such high concentrations paroxetine also potentiated the effect of norepinephrine, although to a greater extent than for 5-HT; this observation is supported by the higher affinity of the NET for norepinephrine than for 5-HT (Andersen, 1989; Tatsumi et al., 1997; Rothman et al., 2001). The selective NET inhibitor desipramine also potentiated the effects of both norepinephrine and 
TABLE 2

$\mathrm{pEC}_{50}$ values for 5-HT and norepinephrine in the absence and presence of monoamine reuptake inhibitors with the respective concentration ratio

The values of control $\mathrm{pEC}_{50}$ corresponds to the mean of independent experiments carried out in the absence (concentration $=0$ ) of reuptake inhibitor. Data are expressed as mean \pm S.E.M. of three to six experiments. The right displacement on the $\mathrm{CRC}$ to 5 -HT or norepinephrine is denoted by the minus (-) signal before the $\mathrm{CR}$ value, which represents the ratio between agonist $\mathrm{EC}_{50}$ in the absence and presence of reuptake inhibitor.

\begin{tabular}{|c|c|c|c|c|c|}
\hline \multirow{2}{*}{ Inhibitor } & \multirow{2}{*}{ Concentration } & \multicolumn{2}{|l|}{5 -HT } & \multicolumn{2}{|c|}{ Norepinephrine } \\
\hline & & $\mathrm{pEC}_{50}$ & $\mathrm{CR}$ & $\mathrm{pEC}_{50}$ & $\mathrm{CR}$ \\
\hline & $n M$ & & & & \\
\hline \multirow[t]{10}{*}{ Paroxetine } & 0 & $6.31 \pm 0.11$ & & $5.83 \pm 0.10$ & \\
\hline & 0.1 & $6.39 \pm 0.16$ & 1.0 & $5.94 \pm 0.10$ & 1.3 \\
\hline & 0.3 & $6.36 \pm 0.17$ & 1.0 & $5.97 \pm 0.10$ & 1.4 \\
\hline & 1 & $6.21 \pm 0.16$ & 1.0 & $6.05 \pm 0.13$ & 1.6 \\
\hline & 3 & $6.18 \pm 0.14$ & 1.0 & $6.05 \pm 0.11$ & 1.6 \\
\hline & 10 & $6.41 \pm 0.06$ & 1.0 & $6.10 \pm 0.11$ & 1.8 \\
\hline & 30 & $6.32 \pm 0.13$ & 1.0 & $6.19 \pm 0.25$ & 2.3 \\
\hline & 100 & $6.74 \pm 0.08$ & 2.7 & $6.61 \pm 0.10$ & 6.0 \\
\hline & 300 & $7.03 \pm 0.11$ & 5.2 & $7.05 \pm 0.11$ & 16.6 \\
\hline & 1000 & $7.03 \pm 0.08$ & 5.2 & $7.35 \pm 0.15$ & 33.1 \\
\hline \multirow[t]{8}{*}{ Fluoxetine } & 0 & $6.62 \pm 0.13$ & & $5.90 \pm 0.10$ & \\
\hline & 1 & $6.48 \pm 0.13$ & -1.3 & $5.66 \pm 0.08$ & -1.7 \\
\hline & 3 & $6.42 \pm 0.18$ & -1.6 & $5.80 \pm 0.12$ & -1.2 \\
\hline & 10 & $6.48 \pm 0.20$ & -1.4 & $5.71 \pm 0.08$ & -1.5 \\
\hline & 30 & $6.33 \pm 0.20$ & -1.9 & $6.12 \pm 0.14$ & 1.6 \\
\hline & 100 & $6.12 \pm 0.23$ & -3.1 & $6.23 \pm 0.07$ & 2.1 \\
\hline & 300 & ND & & $6.33 \pm 0.10$ & 2.7 \\
\hline & 1000 & ND & & $6.21 \pm 0.14$ & 2.0 \\
\hline \multirow[t]{3}{*}{ Desipramine } & 0 & $6.26 \pm 0.15$ & & $5.70 \pm 0.12$ & \\
\hline & 10 & $6.52 \pm 0.19$ & 1.8 & $6.72 \pm 0.17$ & 10.5 \\
\hline & 30 & $6.87 \pm 0.19$ & 4.1 & ND & \\
\hline
\end{tabular}

ND, Not determined.

5-HT, further supporting the role of the NET in the removal of these two agonists in the CE. Although the presence of the SERT has been reported in epithelial, endothelial, and mast cells of the rat caput epididymis by immunohistochemistry (Jiménez-Trejo et al., 2007), we are not aware of studies describing its presence in epididymal smooth muscle. This may indicate the existence of region- and cell-specific mechanisms for 5-HT removal in the epididymis. It is worthwhile to establish the mechanisms of 5-HT removal in the epididymis in vivo considering both adverse and therapeutic effects of SSRIs on sperm parameters as well as on ejaculatory function (Giuliano and Clément, 2005; Kendirci et al., 2007; Rowland et al., 2010; Tanrikut et al., 2010; Abu El-Hamd and Abdelhamed, 2018).

It is known that 5-HT contracts vascular smooth muscles in vitro through $\alpha_{1}$-AR activation (Innes, 1962; Purdy et al.,
1987; Shaw et al., 2000). Our results showed that part of the 5-HT-mediated contraction of the CE smooth muscle is due to activation of $\alpha_{1}$-ARs. Indeed, the selective $\alpha_{1}$-AR antagonist prazosin, which exhibits low affinity for serotonergic receptors (Norman et al., 1985; Cossery et al., 1987; Lyon et al., 1987; Pauwels et al., 1993), antagonized 5-HT-induced contraction, yielding an estimated potency of $\mathrm{p} A_{2}=\sim 8.9$ (Table 3 ) that correlated with the value obtained for prazosin against norepinephrine as well with previous reports of $\mathrm{p} K_{\mathrm{B}}$ values at $\alpha_{1}$-ARs (Pupo, 1998; Lima et al., 2005). Moreover, the Schild plot for prazosin against 5 -HT yielded a regression line with a slope that was less than theoretical unity, indicating that 5-HT activates other receptor populations in addition to $\alpha_{1}$-ARs.

Considering that the presence of $5-\mathrm{HT}$ G protein-coupled receptors (at least $5-\mathrm{HT}_{1 \mathrm{~A}}, 5-\mathrm{HT}_{1 \mathrm{~B}}$, and $5-\mathrm{HT}_{2 \mathrm{~B}}$ ) has already been demonstrated in the rat epididymis by histochemical and pharmacological approaches (Leung et al., 1999; JiménezTrejo et al., 2007), it is reasonable to hypothesize that the 5-HT metabotropic receptor(s) may be involved in the contractions of the CE smooth muscle to 5-HT. To explore this, the effects of selective 5-HT receptor antagonists on 5-HT-induced contractions were determined in the presence of desipramine to block the removal of 5 -HT by the NET and prazosin to antagonize $\alpha_{1}$-ARs.

The potencies found for ketanserin ( 9.4) and fluoxetine (7.4) in antagonizing the contractions of the CE to 5-HT are consistent with the participation of $5-\mathrm{HT}_{2 \mathrm{~A}} / 5-\mathrm{HT}_{2 \mathrm{C}}$. This is due to the limited selectivity of ketanserin (Roth et al., 1992; Boess and Martin, 1994; Glennon et al., 2002; Knight et al., 2004) and fluoxetine (Sánchez and Hyttel, 1999; Rothman et al., 2000; Knight et al., 2004) for $5-\mathrm{HT}_{2 \mathrm{~A}}$ over $5-\mathrm{HT}_{2 \mathrm{C}}$ receptors, and vice versa, thereby showing a weak ability to discriminate between $5-\mathrm{HT}_{2 \mathrm{~A}}$ and $5-\mathrm{HT}_{2 \mathrm{C}}$ receptors. However, whereas mRNA encoding $5-\mathrm{HT}_{2 \mathrm{~A}}$ receptors was readily detected in the CE, transcripts for $5-\mathrm{HT}_{2 \mathrm{C}}$ were not. Thus, it is likely that $5-\mathrm{HT}_{2 \mathrm{~A}}$ receptors have an important role in the contractions induced by 5 -HT in the rat CE. It is worth noting that ketanserin presented insurmountable behavior against 5 -HT in the $\mathrm{CE}$. This may result from hemi-equilibrium, where the slow dissociation of ketanserin from the receptor within the short time frame required for the contraction leads to reduction in the observed 5-HT maximal response (Kenakin et al., 2006). Interestingly, ketanserin also presented insurmountable antagonism in the contractions induced by 5-HT in the rat uterus, another tissue whose contractions are fast and transient (Ichida et al., 1983).
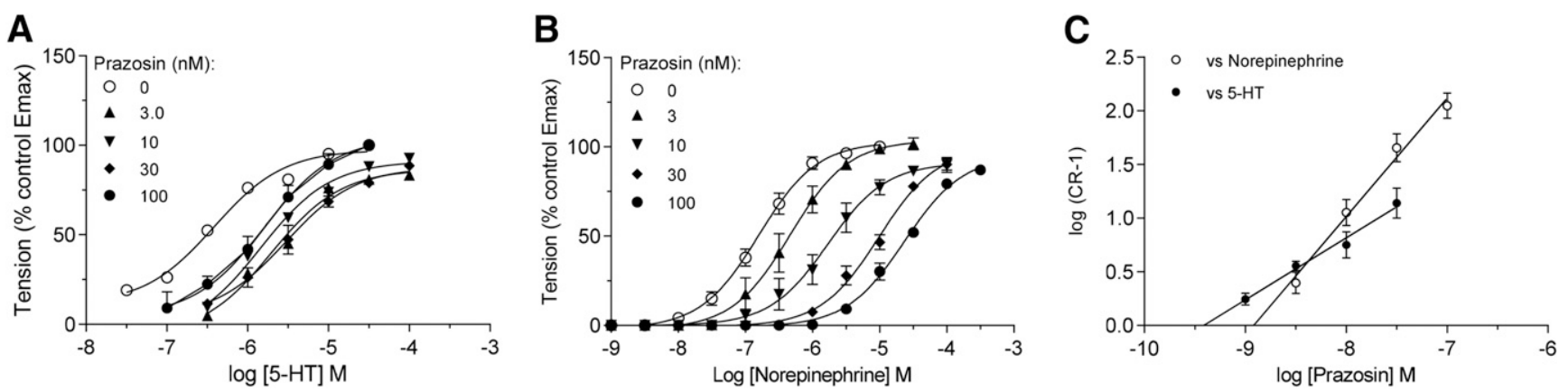

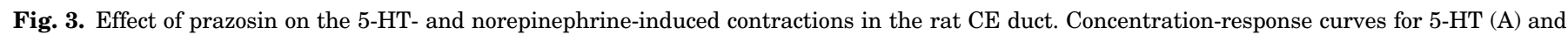

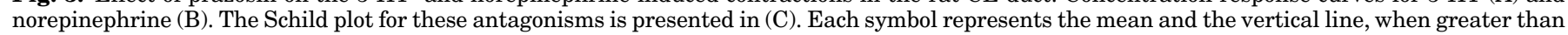
the symbol, represents the S.E.M. of independent experiments performed with CE ducts from three to six rats. 
A

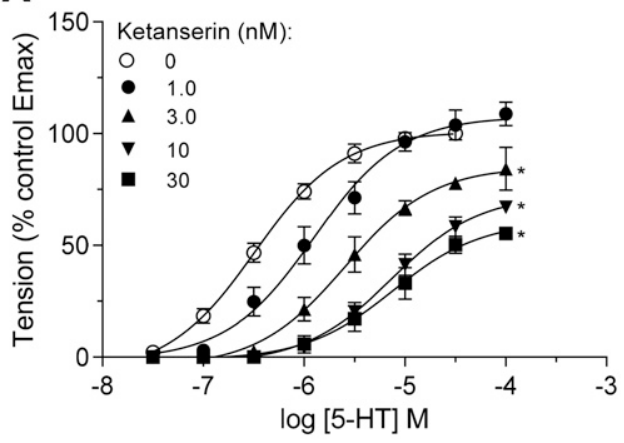

C

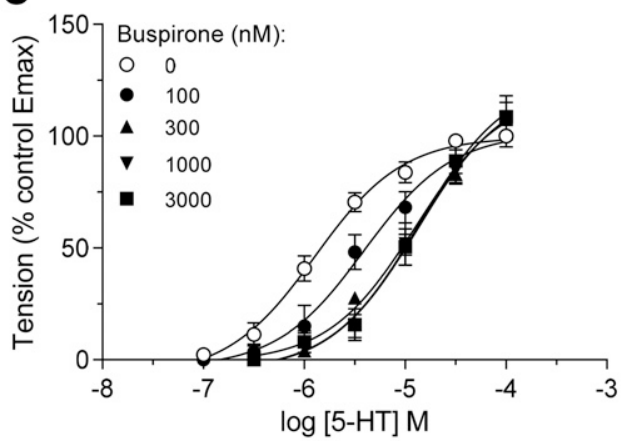

E

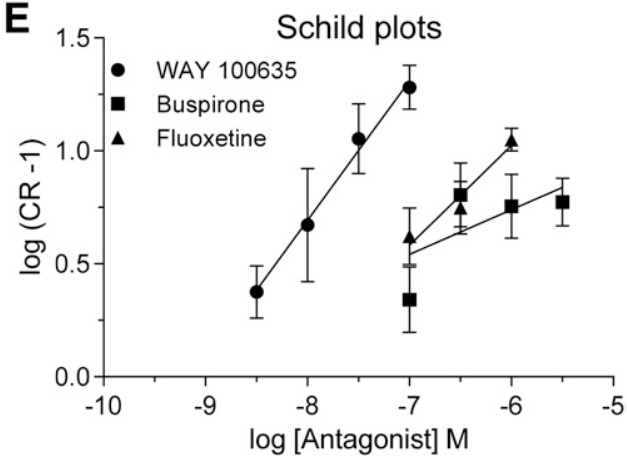

B

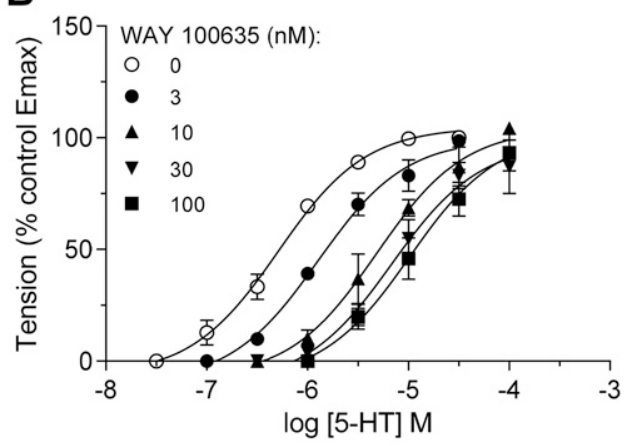

D

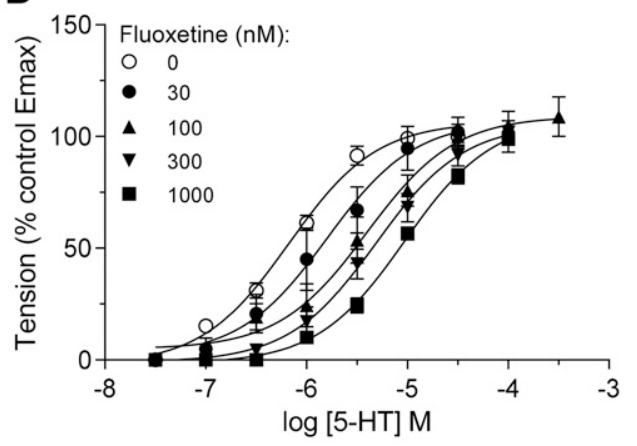

Fig. 4. Effect of 5-HT receptor antagonists on the 5-HT-induced contractions in the rat $\mathrm{CE}$ duct. Concentrationresponse curves to 5 -HT in the presence of increasing concentrations of ketanserin (A), WAY 100635 (B), buspirone (C), and fluoxetine (D). All curves were performed in the presence of $100 \mathrm{nM}$ prazosin, which was included in the inhibitor cocktail. The Schild plot for these antagonisms is presented in (E). Each symbol represents the mean and the vertical line, when greater than the symbol, represents the S.E.M. of independent experiments performed with $\mathrm{CE}$ ducts from three to four rats. * Denotes the mean depressed maximal response.
In addition to the participation of $5-\mathrm{HT}_{2 \mathrm{~A}}$ receptors, we also found evidence for the involvement of $5-\mathrm{HT}_{1 \mathrm{~A}}$ in the contractions induced by 5 -HT in the $\mathrm{CE}$. The contractions induced by 5 -HT were antagonized with high potency by the selective $5-\mathrm{HT}_{1 \mathrm{~A}}$ ligands WAY-100635 $\left(\mathrm{p} A_{2}=\sim 8.9\right)$ and buspirone $\left(\mathrm{p} A_{2}\right.$ $=\sim 7.3$ ); however, the Schild slopes were much less than unity, further supporting the participation of multiple 5-HT receptors. Indeed, our RT-PCR experiments demonstrated that $5-\mathrm{HT}_{1 \mathrm{~A}}$ and
5- $\mathrm{HT}_{1 \mathrm{~B}}$ transcripts are abundantly present in the rat $\mathrm{CE}$. However, additional studies are warranted to investigate the role of $5-\mathrm{HT}_{1 \mathrm{~B}}$ in the contraction of rat $\mathrm{CE}$ by $5-\mathrm{HT}$.

A dense network of interstitial serotonergic fibers has been identified in close proximity to the smooth muscle layer of the distal segment of the CE (Leung et al., 1999). This pattern of innervation is similar to the sympathetic innervation, which is known to play a major role in the contraction of epididymal

TABLE 3

Estimated $\mathrm{p} A_{2}$ values of selective antagonists against contractile responses elicited by 5 -HT in isolated rat $\mathrm{CE}$ duct

Mean \pm S.E.M. When the Schild plot slopes were different from unity, the $\mathrm{p} A_{2}$ values were calculated using the lowest positive values of $\log (\mathrm{CR}-1) ; n$ denotes number of CE preparations.

\begin{tabular}{lllcc}
\hline \multicolumn{1}{c}{ Antagonist } & \multicolumn{1}{c}{ Agonist } & $n$ & $\mathrm{pA}_{2}$ & Schild Slope (95\% Confidence Interval) \\
\hline Prazosin & Norepinephrine & 4 & $8.92 \pm 0.06$ & $1.10 \pm 0.10(0.88-1.33)$ \\
Prazosin & 5-HT & 4 & $8.89 \pm 0.20$ & $0.58 \pm 0.09(0.37-0.79)$ \\
Ketanserin & 5-HT & 6 & $9.36 \pm 0.17$ & $\left.-\bar{a}^{-13}-0.75\right)$ \\
Fluoxetine & 5-HT & 6 & $7.41 \pm 0.16$ & $0.44 \pm 0.14(0.13-0.74 \pm 0.97)$ \\
WAY 100635 & 5-HT & 4 & $8.90 \pm 0.04$ & $0.62 \pm 0.13(0.26-0.97)$ \\
Buspirone & 5-HT & 4 & $7.34 \pm 0.14$ & $0.20 \pm 0.13(-0.07$ to 0.47$)$
\end{tabular}

${ }^{a}$ This could not be examined because the antagonism was insurmountable. 


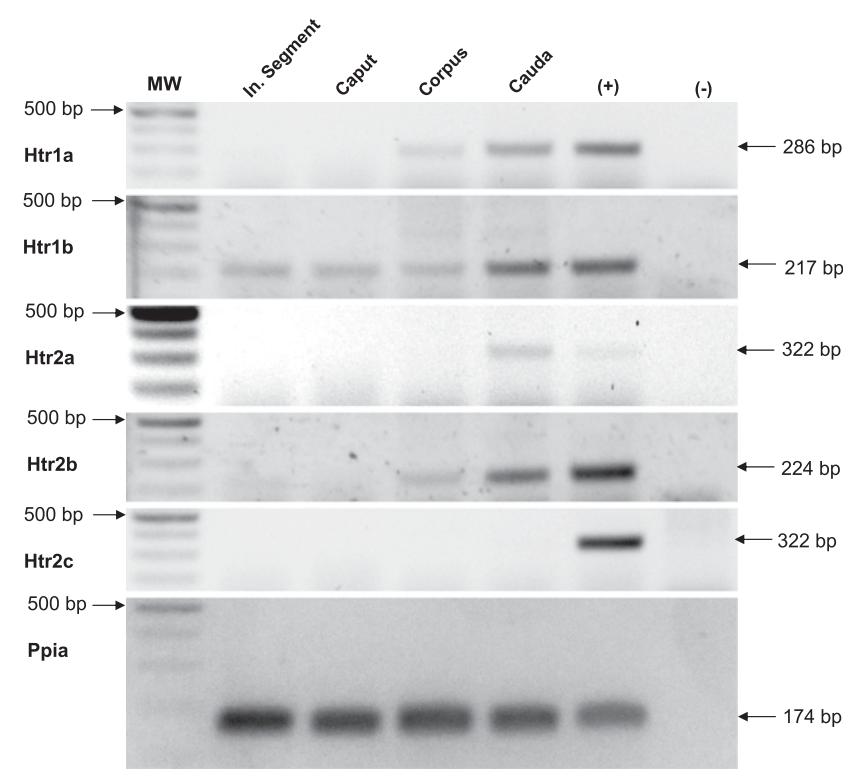

Fig. 5. Expression of 5-HT receptors in the rat epididymis. Representative inverted image of agarose gels showing the detection of Htr $1 a, 1 b$, $2 a, 2 b$, and $2 c$ mRNAs by RT-PCR as indicated (right arrow). MW indicates a 100 base pair (bp) standard DNA ladder. Ppia mRNA was used as the internal control. Legend: (+) positive control (brain for Htr1a, $1 b, 2 a, 2 c$, and Ppia or testis for Htr2b); (-) negative control $\left(\mathrm{H}_{2} \mathrm{O}\right)$. Results are representative of experiments performed in duplicate with tissues from one rat.

smooth muscle, transport of spermatozoa, and fertility (Kempinas et al., 1998; Ricker, 1998). In agreement with these observations, our results showed that the abundance of all 5-HT receptor transcripts analyzed was higher in the cauda epididymis when compared with proximal regions of this organ. It is recognized that proximal and distal epididymal regions display different morphologic and functional properties (Hinton and Robaire, 2015). Thus, further studies are warranted to understand the roles of 5-HT as a factor regulating the smooth muscle contractions also in the proximal regions of the epididymis.

It has been proposed that 5 -HT regulates anion secretion from the $\mathrm{CE}$ epithelium via $5-\mathrm{HT}_{1 \mathrm{~B}}$ and $5-\mathrm{HT}_{2 \mathrm{~B}}$ receptors (Leung et al., 1999) and our data provide new insights into the potential roles of 5-HT as a signaling molecule regulating sperm transport and storage in the epididymis. Our study further contributes to the understanding of the peripheral effects of serotonergic drugs in the male reproductive tract.

\section{Authorship Contributions}

Participated in research design: Mueller, Kiguti, Silva, Pupo.

Conducted experiments: Mueller, Kiguti.

Contributed new reagents or analytic tools: Silva, Pupo.

Performed data analysis: Mueller, Kiguti, Silva, Pupo.

Wrote or contributed to the writing of the manuscript: Mueller, Kiguti, Silva, Pupo.

\section{References}

Abu El-Hamd M and Abdelhamed A (2018) Comparison of the clinical efficacy and safety of the on-demand use of paroxetine, dapoxetine, sildenafil and combined dapoxetine with sildenafil in treatment of patients with premature ejaculation: a randomised placebo-controlled clinical trial. Andrologia 50:e12829.

Alexander SP, Christopoulos A, Davenport AP, Kelly E, Marrion NV, Peters JA, Faccenda E, Harding SD, Pawson AJ, Sharman JL, et al.; CGTP Collaborators (2017a) The concise guide to pharmacology 2017/18: G protein-coupled receptors. $\mathrm{Br} J$ Pharmacol 174 (Suppl 1):S17-S129.

Alexander SP, Peters JA, Kelly E, Marrion NV, Faccenda E, Harding SD, Pawson AJ, Sharman JL, Southan C, and Davies JA; CGTP Collaborators (2017b) The concise guide to pharmacology 2017/18: ligand-gated ion channels. $\mathrm{Br} J$ Pharmacol 174 (Suppl 1):S130-S159.

Anderson ME, Paparo AA, and Martan J (1979) Paraformaldehyde-induced fluorescence as a histochemical test for 5-hydroxytryptamine in the epididymis of the opossum. J Anat 129:141-149.

Andersen PH (1989) The dopamine inhibitor GBR 12909: selectivity and molecular mechanism of action. Eur $J$ Pharmacol 166:493-504.

Arunlakshana O and Schild HO (1959) Some quantitative uses of drug antagonists. Br J Pharmacol Chemother 14:48-58.

Berger M, Gray JA, and Roth BL (2009) The expanded biology of serotonin. Annu Rev Med 60:355-366.

Boess FG and Martin IL (1994) Molecular biology of 5-HT receptors. Neuropharmacology 33:275-317.

Bolden-Watson C and Richelson E (1993) Blockade by newly-developed antidepressants of biogenic amine uptake into rat brain synaptosomes. Life Sci 52:1023-1029. Bonhaus DW, Weinhardt KK, Taylor M, DeSouza A, McNeeley PM, Szczepanski K, Fontana DJ, Trinh J, Rocha CL, Dawson MW, et al. (1997) RS-102221: a novel high affinity and selective, 5-HT2C receptor antagonist. Neuropharmacology 36: $621-629$

Campos MG, Oropeza MV, Lemus AE, Garcia GA, Reynoso ME, Campos P, and Ponce-Monter H (1999) The androgenic effect of norethisterone and $5 \alpha$-norethisterone on the contractile response of the rat vas deferens to methoxamine and serotonin. Life Sci 64:PL227-PL233.

Cossery JM, Gozlan H, Spampinato U, Perdicakis C, Guillaumet G, Pichat L, and Hamon $\mathrm{M}$ (1987) The selective labelling of central 5-HT $1 \mathrm{~A}$ receptor binding sites by $\left[{ }^{3} \mathrm{H}\right] 5$-methoxy-3-(di-n-propylamino)chroman. Eur $J$ Pharmacol 140: 143-155.

Giuliano F and Clément P (2005) Physiology of ejaculation: emphasis on serotonergic control. Eur Urol 48:408-417.

Glennon RA, Metwally K, Dukat M, Ismaiel AM, De los Angeles J, Herndon J, Teitler M, and Khorana N (2002) Ketanserin and spiperone as templates for novel serotonin 5-HT(2A) antagonists. Curr Top Med Chem 2:539-558.

Gonzales GF, Garcia-Hjarles M, and Velasquez G (1992) Hyperprolactinaemia and hyperserotoninaemia: their relationship to seminal quality. Andrologia 24:95-100.

Hannon J and Hoyer D (2008) Molecular biology of 5-HT receptors. Behav Brain Res 195: $198-213$.

Hay DWP and Wadsworth RM (1982) The contractile effects of 5-hydroxytryptamine on the rat isolated vas deferens. Br J Pharmacol 77:605-613.

Hinton B and Robaire B (2015) The epididymis, in Knobil and Neill's Physiology of Reproduction (Plant T and Zeleznik A, eds) 691-771, Academic Press, San Diego, CA.

Hoyer D, Clarke DE, Fozard JR, Hartig PR, Martin GR, Mylecharane EJ, Saxena PR, and Humphrey PP (1994) International Union of Pharmacology classification of receptors for 5-hydroxytryptamine (serotonin). Pharmacol Rev 46:157-203.

Ichida S, Hayashi T, and Terao M (1983) Selective inhibition by ketanserin and spiroperidol of 5-HT-induced myometrial contraction. Eur J Pharmacol 96:155-158.

Innes IR (1962) An action of 5-hydroxytryptamine on adrenaline receptors. $\mathrm{Br} J$ Pharmacol Chemother 19:427-441.

Jannini EA, Ciocca G, Limoncin E, Mollaioli D, Di Sante S, Gianfrilli D, Lombardo F, and Lenzi A (2015) Premature ejaculation: old story, new insights. Fertil Steril 104: 1061-1073

Jelinsky SA, Turner TT, Bang HJ, Finger JN, Solarz MK, Wilson E, Brown EL, Kopf GS, and Johnston DS (2007) The rat epididymal transcriptome: comparison of segmental gene expression in the rat and mouse epididymides. Biol Reprod 76: $561-570$.

Jiménez-Trejo F, Tapia-Rodríguez M, Queiroz DBC, Padilla P, Avellar MCW, Manzano PR, Manjarrez-Gutiérrez G, and Gutiérrez-Ospina G (2007) Serotonin concentration, synthesis, cell origin, and targets in the rat caput epididymis during sexual maturation and variations associated with adult mating status: morphological and biochemical studies. J Androl 28:136-149.

Kempinas WD, Suarez JD, Roberts NL, Strader LF, Ferrell J, Goldman JM, Narotsky MG, Perreault SD, Evenson DP, Ricker DD, et al. (1998) Fertility of rat epididymal sperm after chemically and surgically induced sympathectomy. Biol Reprod 59:897-904.

Kenakin T, Jenkinson S, and Watson C (2006) Determining the potency and molecular mechanism of action of insurmountable antagonists. J Pharmacol Exp Ther 319:710-723.

Kendirci M, Salem E, and Hellstrom WJG (2007) Dapoxetine, a novel selective serotonin transport inhibitor for the treatment of premature ejaculation. Ther Clin Risk Manag 3:277-289.

Kilkenny C, Browne WJ, Cuthill IC, Emerson M, and Altman DG (2010) Improving bioscience research reporting: the ARRIVE guidelines for reporting animal research. PLoS Biol 8:e1000412.

Kim SW and Paick JS (2004) Peripheral effects of serotonin on the contractile responses of rat seminal vesicles and vasa deferentia. J Androl 25:893-899.

Kinson GA, MacDonald NE, and Liu CC (1973) The effects of melatonin and serotonin on blood flow fraction and testosterone metabolism in selected organs of the male rat. Can J Physiol Pharmacol 51:313-318.

Knight AR, Misra A, Quirk K, Benwell K, Revell D, Kennett G, and Bickerdike M (2004) Pharmacological characterisation of the agonist radioligand binding site of $5-\mathrm{HT}_{2 \mathrm{~A}}, 5-\mathrm{HT}_{2 \mathrm{~B}}$ and $5-\mathrm{HT}_{2 \mathrm{C}}$ receptors. Naunyn Schmiedebergs Arch Pharmacol 370:114-123.

Kormano M and Penttilä A (1968) Distribution of endogenous and administered 5-hydroxytryptamine in the rat testis and epididymis. Ann Med Exp Biol Fenn 46: 468-473.

Leung GP, Dun SL, Dun NJ, and Wong PY (1999) Serotonin via 5- $\mathrm{HT}_{1 \mathrm{~B}}$ and $5-\mathrm{HT}_{2 \mathrm{~B}}$ receptors stimulates anion secretion in the rat epididymal epithelium. $J$ Physiol 519:657-667.

Lima V, Mueller A, Kamikihara SY, Raymundi V, Alewood D, Lewis RJ, Chen Z, Minneman KP, and Pupo AS (2005) Differential antagonism by conotoxin $\rho$-TIA of 
contractions mediated by distinct $\alpha_{1}$-adrenoceptor subtypes in rat vas deferens, spleen and aorta. Eur J Pharmacol 508:183-192.

Lyon RA, Davis KH, and Titeler M (1987) 3H-DOB (4-bromo-2,5-dimethoxyphenylisopropylamine) labels a guanyl nucleotide-sensitive state of cortical 5-HT2 receptors. Mol Pharmacol 31:194-199.

Ni YG and Miledi R (1997) Blockage of $5 \mathrm{HT}_{2 \mathrm{C}}$ serotonin receptors by fluoxetine (Prozac). Proc Natl Acad Sci USA 94:2036-2040.

Norman AB, Battaglia G, and Creese I (1985) [3H]WB4101 labels the 5-HT1A serotonin receptor subtype in rat brain. Guanine nucleotide and divalent cation sensitivity. Mol Pharmacol 28:487-494.

Owens MJ, Morgan WN, Plott SJ, and Nemeroff CB (1997) Neurotransmitter receptor and transporter binding profile of antidepressants and their metabolites. $J$ Pharmacol Exp Ther 283:1305-1322.

Pacini ESA, Castilho ACS, Hebeler-Barbosa F, Pupo AS, and Kiguti LRA (2018) Contraction of rat cauda epididymis smooth muscle to $\alpha_{1}$-adrenoceptor activation is mediated by $\alpha_{1 \mathrm{~A}}$-adrenoceptors. J Pharmacol Exp Ther 366:21-28.

Pauwels PJ, Van Gompel P, and Leysen JE (1993) Activity of serotonin (5-HT) receptor agonists, partial agonists and antagonists at cloned human 5 - $\mathrm{HT}_{1 \mathrm{~A}}$ receptors that are negatively coupled to adenylate cyclase in permanently transfected HeLa cells. Biochem Pharmacol 45:375-383.

Pedroso SP, de Souza BP, Jurkiewicz A, Juriewicz NH, and da Silva Junior ED (2017) Effects of in vitro, acute and chronic treatment with fluoxetine on the sympathetic neurotransmission of rat vas deferens. Auton Neurosci 203:17-24.

Pupo AS (1998) Functional effects of castration on $\alpha_{1}$-adrenoceptors in rat vas deferens. Eur J Pharmacol 351:217-223.

Purdy RE, Murray DL, and Stupecky GL (1987) Receptors for 5-hydroxytryptamine in rabbit blood vessels: activation of alpha adrenoceptors in rabbit thoracic aorta. $J$ Pharmacol Exp Ther 240:535-541.

Queiróz DBC, Mendes FR, Porto CS, and Avellar MCW (2002) $\alpha_{1}$-Adrenoceptor subtypes in rat epididymis and the effects of sexual maturation. Biol Reprod 66 508-515.

Reist M, Pfaffl MW, Morel C, Meylan M, Hirsbrunner G, Blum JW, and Steiner A (2003) Quantitative mRNA analysis of eight bovine 5-HT receptor subtypes in brain, abomasum, and intestine by real-time RT-PCR. $J$ Recept Signal Transduct Res 23:271-287.

Ricker DD (1998) The autonomic innervation of the epididymis: its effects on epididymal function and fertility. $J$ Androl 19:1-4.

Ricker DD, Crone JK, Chamness SL, Klinefelter GR, and Chang TS (1997) Partial sympathetic denervation of the rat epididymis permits fertilization but inhibits embryo development. J Androl 18:131-138.

Roth BL, Ciaranello RD, and Meltzer HY (1992) Binding of typical and atypical antipsychotic agents to transiently expressed 5-HT1C receptors. J Pharmacol Exp Ther 260:1361-1365.

Rothman RB, Baumann MH, Dersch CM, Romero DV, Rice KC, Carroll FI, and Partilla JS (2001) Amphetamine-type central nervous system stimulants release norepinephrine more potently than they release dopamine and serotonin. Synapse 39:32-41.

Rothman RB, Baumann MH, Savage JE, Rauser L, McBride A, Hufeisen SJ, and Roth BL (2000) Evidence for possible involvement of $5-\mathrm{HT}_{2 \mathrm{~B}}$ receptors in the cardiac valvulopathy associated with fenfluramine and other serotonergic medications. Circulation 102:2836-2841.

Rowland D, McMahon CG, Abdo C, Chen J, Jannini E, Waldinger MD, and Ahn TY (2010) Disorders of orgasm and ejaculation in men. J Sex Med 7 1668-1686.

Sanbe A, Tanaka Y, Fujiwara Y, Tsumura H, Yamauchi J, Cotecchia S, Koike K, Tsujimoto $\mathrm{G}$, and Tanoue A (2007) $\alpha_{1}$-Adrenoceptors are required for normal male sexual function. Br J Pharmacol 152:332-340.

Sánchez C and Hyttel J (1999) Comparison of the effects of antidepressants and their metabolites on reuptake of biogenic amines and on receptor binding. Cell Mol Neurobiol 19:467-489.

Shaw AM, Brown C, Irvine J, Bunton DC, and MacDonald A (2000) Role of the $5-\mathrm{HT}_{2 \mathrm{~A}}$ receptor and $\alpha_{1}$-adrenoceptor in the contractile response of rat pulmonary artery to 5-HT in the presence and absence of nitric oxide. Pulm Pharmacol Ther 13:277-285.

Silva EJR, Queiróz DBC, Honda L, and Avellar MCW (2010) Glucocorticoid receptor in the rat epididymis: expression, cellular distribution and regulation by steroid hormones. Mol Cell Endocrinol 325:64-77.

Singh US, Kumar MV, and Panda JN (1987) Changes in angiotensin converting enzyme in testes and epididymis of rat due to serotonin administration. Andrologia 19:153-156.

Solomon HM, Wier PJ, Ippolito DL, and Toscano TV (1997) Effect of prazosin on sperm transport in male rats. Reprod Toxicol 11:627-631.

Steidle CP, Cohen ML, Hoover DM, and Neubauer BL (1989) Comparative contractile responses among ventral, dorsal, and lateral lobes of the rat prostate. Prostate 15:53-63

Tanrikut C, Feldman AS, Altemus M, Paduch DA, and Schlegel PN (2010) Adverse effect of paroxetine on sperm. Fertil Steril 94:1021-1026.

Tatsumi M, Groshan K, Blakely RD, and Richelson E (1997) Pharmacological profile of antidepressants and related compounds at human monoamine transporters. Eur $J$ Pharmacol 340:249-258.

Ventura S and Pennefather JN (1991) Sympathetic co-transmission to the cauda epididymis of the rat: characterization of postjunctional adrenoceptors and purinoceptors. Br J Pharmacol 102:540-544.

White CW, Choong YT, Short JL, Exintaris B, Malone DT, Allen AM, Evans RJ, and Ventura S (2013) Male contraception via simultaneous knockout of $\alpha_{1 \mathrm{~A}}$ adrenoceptors and P2X1-purinoceptors in mice. Proc Natl Acad Sci USA 110: 20825-20830.

Address correspondence to: Dr. Erick J. R. Silva, Department of Pharmacology, Institute of Biosciences, UNESP - São Paulo State University, Professor Dr. Antonio Celso W. Zanin Street, Rubião Junior District, Botucatu-SP 18618-689, Brazil. E-mail: ejr.silva@unesp.br; or Dr. André S. Pupo, Department of Pharmacology, Institute of Biosciences, UNESP - São Paulo State University, Professor Dr. Antonio Celso W. Zanin Street, Rubião Junior District, Botucatu-SP 18618-689, Brazil. E-mail: aspupo@ibb.unesp.br 